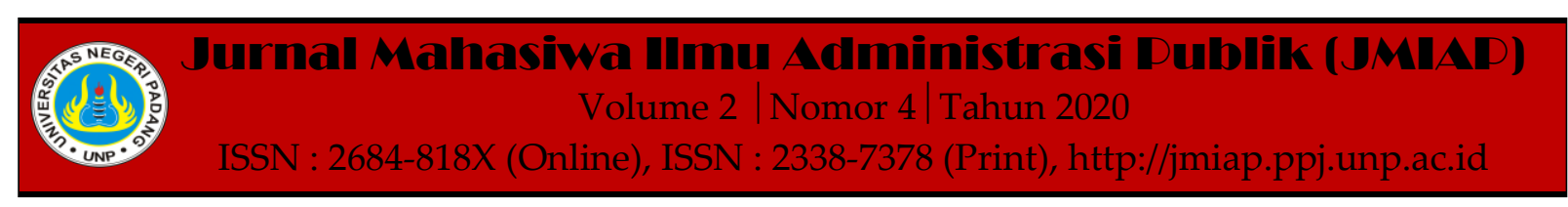

\title{
PARTISIPASI POLITIK MAHASISWA UNIVERSITAS NEGERI PADANG SEBAGAI BAGIAN DARI KEKUATAN POLITIK DALAM MEMPENGARUHI KEBIJAKAN RKUHP
}

\author{
Rima Arfa Solia ${ }^{1(a)}$, Lince Magriasti $^{2(b)}$ \\ ${ }^{1}$ Jurusan Ilmu Administrasi Negara, Universitas Negeri Padang \\ ${ }^{2}$ Jurusan Ilmu Administrasi Negara, Universitas Negeri Padang \\ a) rimaarfa1@gmail.com, ${ }^{b)}$ lincemagriasti@fis.unp.ac.id
}

\begin{abstract}
The RKUHP policy is the result of a regulation made by the DPR in 2019 at the end of its term of office, because the content of this regulation contains a lot of ombiguity and is controversial by students asking the government to re-examine this regulation, participation by students becomes a political force when the president finally takes it. action by resigning the endorsement of this policy to conduct a review, in practice the students of the State University of Padang (UNP) were a part of political power at that time, various ways of participation such as demonstrations, discussions, and the use of social media were carried out by UNP students. The biggest factor that affects the participation of UNP students is experience in organizations and the influence of information on social media. It is recognized that UNP students have high political awareness but it is inversely related to the relatively low trust in the government, thus giving birth to a form of militant-radical political participation.

Keywords : Political Participation, Political Power, Student, RKUHP

Corresponding author. Email. rimaarfal@gmail.com

How to cite this article. Solia, R. Arfa \& Magriasti, Lince. (2020). Partisipasi Politik Mahasiswa Universitas Negeri Padang sebagai Bagian dari Kekuatan Politik dalam Mempengaruhi Kebijakan RKUHP. Jurnal Mahasiwa Ilmu Administrasi Publik (JMIAP) Jurusan Ilmu Administrasi Negara Fakultas Ilmu Sosial Universitas Negeri Padang, Volume 2 (4), Hal. 10-19.

http://jmiap.ppj.unp.ac.id

ISSN : 2684-818X (Online), ISSN : 2338-7378 (Print)

Copyright $\odot 2020$. Published by Labor Jurusan Ilmu Administrasi Negara FIS UNP, Padang
\end{abstract}




\section{PENDAHULUAN}

Mahasiswa memiliki peran dalam sistem perpolitikan Indonesia, hal ini sejalan dengan yang ditulis oleh Andrias (2011:66) dalam majalah ilmiah UNIKOM, ia menyatakan bahwa ramainya kegiatan politik yang dilakukan oleh mahasiswa membuat mahasiswa memiliki peran penting pada masa reformasi ini. Peranya dalam menyuarakan aspirasi dan tuntutan masyarakat membuat mahasiswa memiliki peran pada posisi terdepan dalam menentukan, mengantisipasi dan menjawab setiap persoalan maupun perubahan sosial. Sementara itu, satu hal yang harus diperhatikan di dalam proses politik di Indonesia dewasa ini ialah bahwa disamping sebagai katalisator situasi dan kehendak masyarakat, aktivitas politik mahasiswa dijadikan juga sebagai tolak ukur kepuasaaan masyarakat (Arbi 2012:89).

Mahasiswa mempunyai kemampuan untuk mengukur apa yang dialami oleh masyarakat, serta apa yang diharapkanya dari pemerintah. Apabila nilai-nilai dasar yang layak diperkembangkan di dalam masyarakat, seperti kebebasan mengemukakan pendapat, berkumpul dan kehidupan tidak jauh sekali bedanya dengan lapisan atas masyarakat, sudah tertekan dan menyentuh rasa idealisme mahasiswa maka seluruh mahasiswa terajak untuk melakukan aktivitas politik.Faktor idealisme yang merupakan pendorong bagi kegiatan politik mahasiswa pada umumnya, selama di universitas mahasiswa banyak mengamati masyarakat melalui mata kuliah, penelitian dan praktek di dalam masyarakat. Begitu pula masyarakat memiliki pengetahuan yang cukup mengenai kenegaraan, pemerintahan serta seluk beluk penganturannya (Arbi, 2012: 86-87).

Sementara itu keterlibatan mahasiswa seringkali sebagai bentuk respon kepada pemerintah, pada dasarnya keterlibatan masyarakat memang dibutuhkan dalam pembuatan kebijakan, Dadi (2017:19) mengungkapkan bahwa dalam formulasi kebijakan publik, semestinya ada suatu arena atau tatanan dalam suatu ruang publik yang memungkinkan setiap warga negara ambil bagian dan melakukan komunikasi dalam pengertian politis untuk mengembangkan partisipasi demokratis dalam membicarakan masalah kepentingan umum. Pada pertengahan bulan September sejumlah kalangan masyarakat terutama mahasiswa mengkritisi kebijakan RKUHP yang dikeluarkan oleh DPR RI, mahasiswa UNP merupakan salah satu bagian dari kekuatan politik yang ikut berpartisipasi dalam mempengaruhi kebijakan tersebut. Mahasiswa menolak kebijakan terkait dengan beberapa pasal kontroversial dan mengandung ambiguitas, hal tersebut mereka suarakan kedalam bentuk kajian yang disuarakan melalui media sosial, diskusi, demostrasi.

Sejumlah permasalahan yang timbul dari upaya mahasiswa dalam mempengaruh kebijakan RKUHP yaitu, pengrusakan barang publik, bentrok dengan aparat, adanya dugaan provokasi oleh pihak DPRD, masa yang tidak terkoodinir, hingga penurunan foto presiden. Oleh karena itu berdasarkan pada permasalahan diatas penelitian bertujuan untuk menjelaskan bagaimana kekuatan politik mahasiswa UNP dapat mempengaruhi kebijakan RKUHP, faktor y pendorong partisipasi politik, dan bentuk partisipasi politik.

\section{TINJAUAN PUSTAKA}

\section{Partisipasi Politik}

Menurut Miriam Budiarjo, Partisipasi politik adalah kegiatan seseorang atau kelompok orang untuk ikut serta secara aktif dalam kehidupan politik, yakni dengan cara memilih pemimpin negara dan secara langsung atau tidak langsung, memengaruhi kebijakan pemerintah. Sementara itu, Hungtington dan Nelson dalam Anwar (2015:78-79) memandang bahwa partisipasi politik tidak hanya timbul dari dalam diri warga negara secara sukarela, akan tetapi juga dapat digerakan atau dimobilisasi oleh pihak ketiga. 
Rima Arfa Solia, Lince Magriasti | Partisipasi Politik Mahasiswa Universitas Negeri Padang sebagai Bagian dari Kekuatan Politik dalam Mempengaruhi Kebijakan RKUHP

Dalam negara-negara demokrasi partisipasi politik merupakan hak dari warga negaranya, berdasarkan pada pendapat Ramlan Surbakti, Almond, B.N Marbun, Bonar Simangunsong dan Ibnu Kencana dalam Doni (2010:141-142) mengidentifikasi faktor-faktor yang mempengaruhi partisipasi politik sebagai berikut: 1)Sosial dan Ekonomi, 2) Situasi, 3)Afiliasi Politik Orang Tua, 4) Pengalaman Berorganisasi, 5) Kesadaran Politik, 6) Kepercayaan terhadap Pemerintah.

Sementara itu Subakti dalam Maya (2016:29-30) membagi tipe partipasi masyarakat kedalam:

Pertama Partisipasi Aktif,Merujuk pada masyarakat yang memiliki kesadaran politik tinggi serta yang menunjuk perilaku responsif terhadap kebijakan pemerintah.

Kedua Partisipasi Militan-Radikal yaitu kegiatan warga negara yang senangtiasa menampilkan perilaku tanggap (responsif) terhadap berbagai kebijakan pemerintah. Namun berbeda dari partisipasi aktif, yang cenderung mengutamakan cara-cara konvensional, termasuk didalamnya kekerasan atau dengan kata lain apabila kesadaran politik tinggi tetapi kepercayaan kepada pemerintah sangat rendah, maka akan melahirkan militan radikal.

Ketiga Partisipasi Pasif yaitu kegiatan warga negara yang menerima begitu saja segala kebijakan pemerintah. Jadi, partisipasi pasif cenderung tidak mempersoalkan apapun kebijakan politik yang dibuat pemerintah. Dalam kata lain, apabila kesadaran akan politk rendah namun kepercayaan akan pemerintah tinggi maka akan terbentuk partisipasi yang pasif, Keempat Partisipasi Apatis yaitu warga negara yang sudah tidak mau tahu dengan kebijakan publik yang dilahirkan oleh pemerintah, hal ini biasanya terjadi pada warga negara yang sudah kecewa terhadap pemerintahan dan sistem politik yang ada.

\section{Mahasiswa sebagai Kekuatan Politik}

Kekuatan-kekuatan diartikan sebagai kekuatan-kekuatan politik dalam artian invidual maupun kelembagaan. Dalam pengertian yang sifatnya individual, kekuatan-kekuatan politik yang tidak lain adalah aktor-aktor politik atau orang-orang yang memainkan peranan dalam kehidupan politik. Orang-orang ini terdiri dari pribadipribadi yang hendak mempengaruhi proses pengambilan keputusan politik. Dan secara kelembagaan disini kekuatan-kekuatan politik bisa berupa lembaga-lembaga atau organisasi-organisasi ataupun bentuk lain yang melembaga dan bertujuan untuk mempengaruhi proses pengambilan keputusan politik dalam sistem politik. Miriam Budiardjo dalam Andik (2013:93).

Mahasiswa sebagai kekuatan politik identik dengan sebuah gerakan yang diikuti oleh mahasiswa. Berdasarkan pada skala partisipasi yang dibuat oleh Ae-Rie Lie (1997), Muller dan Grofman (1972), Matulessy (2008), maka Andik (2013:9495) menjabarkan skala partispasi dalam gerakan mahasiswa.

Pertama berpartisipasi dalam demostrasi. Termasuk didalamnya partisipasi dalam rapat menyusun aksi massa, berpartisipasi dalam demonstrasi, melakukan kampanye politik berupa tulisan, pamflet, leafet dan propaganda, mengikuti aksi damai maupun aksi bentrok.

Kedua mengikuti diskusi yang diselenggarakan organisasi gerakan mahasiswa. Partispasi ini mencangkup antara lain; ikut berdiskusi dalam jangka waktu yang lama (hingga malam hari), mengikuti kelompok diskusi mengenai tema-tema perlawanan dan revolusiober.

Ketiga mengikuti aksi solidaritas dengan gerakan sosial lainya. Partisipasi ini mencangkup antara lain ikut serta dalam demostrasi buruh,petani,LSM,dan kelompok progresif lainya.

Keempat melakukan musyawarah. Membangun koneksi dengan gerakan mahasiswa atau elemen gerakan sosial yang lain. Selain itu konsolidasi juga berarti menyamakan suhu dan membahas tematema, terkait keadaan lokal hingga nasional berhubungan dengan strategi dan taktik gerakan. 


\section{Konsep Kebijakan Publik}

Kebijakan dapat didefenisikan sebagai serangkaian rencana program aktivitas, aksi, keputusan, sikap, untuk bertindak maupun tidak bertindak yang dilakukan oleh pihak (aktor-aktor), sebagai tahapan untuk penyelesaian masalah yang dihadapi. Penetapan kebijakan merupakan suatu faktor penting bagi organisasi untuk mencapai tujuannya. Dikutip dari pendapat Ripley dalam Taufiq (2014:201-202) menyebutkan bahwasanya ruang lingkup formulasi kebijakan publik lebih menekankan pada tahapan : Agenda Setting, Agenda Pemerintah, Formulasi dan legitimasi, serta pengambilan dan pengumuman kebijkan kebijakan untuk mencapai sasaran seperti apa yang telah dijelaskan.

Dikutip dari pendapat Ripley dalam Sholih (2016:201-202) menyebutkan bahwasanya ruang lingkup formulasi kebijakan publik lebih menekankan pada tahapan : Agenda Setting, Agenda Pemerintah, Formulasi dan legitimasi, serta pengambilan dan pengumuman kebijkan kebijakan untuk mencapai sasaran seperti apa yang telah dijelaskan di atas. Lebih lanjut O'Jones dalam sholih menjelaskan bahwasanya ada empat varian kelompok kepentingan bila dilihat dari interest dan akses serta kebutuhan masyarakat pada perumusan kebijakan publik yaitu :

1) Kelompok kepentingan yang terorganisir dengan baik dengan akses yang mapan;

2) Kelompok kepentingan yang terorganisisr dengan baik tanpa akses yang mapan;

3) Kelompok kepentingan yang tidak terorganisir dengan baik tetapi memiliki akses yang mapan;

4) Kelompok kepentingan yang tidak terorganisir sekaligus juga tidak memiliki akses yang mapan

Proses analisis kebijakan publik adalah serangkaian aktivitas intelektual yang dilakukan di dalam proses kegiatan yang bersifat politis. Aktivitas politis tersebut nampak dalam serangkaian kegiatan yang mencangkup penyusunan agenda, formulasi kebijakan, implementasi kebijakan, dan penilaian kebijakan. Sedangkan aktivitas perumusan masalah, forcasting, rekomendasi kebijakan, monitoring, dan evaluasi adalah aktivitas yang bersifat intelektual. Berikut dijelaskan tahap analisis kebijakan dan karakteristiknya:

1) Perumusan masalah : Memberikan informasi mengenai kondisi-kondisi yang menimbulkan masalah.

2) Forcasting (Peramalam) : Memberikan informasi mengenai konsekuensi dimasa mendatang dari beberapa alternatif kebijakan, termasuk apabila tidak membuat kebijakan.

3) Rekomendasi Kebijakan :

Memberikan informasi mengenai manfaat bersih dari setiap alternatif dan merekomendasikan alternatif kebijakan yang memberikan manfaat bersih paling tinggi.

4) Monitoring Kebijakan : Memberikan informasi mengenai konsekuensi sekarang dan masa lalu dari diterapkanya alternatif kebijakan termasuk kendala-kendalanya.

5) Evaluasi Kebijakan

Memberikan informasi mengenai kinerja.

\section{Rancangan Kitab Undang Undang Hukum Pidana (RKUHP) 2019}

KUHP digunakan di Indonesia merupakan peninggalan hukum kolonial Belanda, sejatinya ini sudah digunakan Indonesia selama satu abad lebih. Diberi nama asli Wetbock van Strafrecht voor Nederlancsh Indie atau WvSNI, merupakan hasil hukum turunan dari Wvs Belanda yang dirumuskan pada tahun 1881 dan digunakan di Belanda pada 1886. Memasuki masa penjajahan Jepang dapat disebutkan bahwasanya diberlakukan dua aturan pidana secara bersamaan, yaitu aturan pidana peninggalan pemerintah kolonial Belanda WvSNI. Lebih lanjut setelah merdeka, WvSNI diadopsi menjadi hukum nasional melalui Undang-Undang Nomor 1 Tahun 1946 tentang Peraturan 
Rima Arfa Solia, Lince Magriasti | Partisipasi Politik Mahasiswa Universitas Negeri Padang sebagai Bagian dari Kekuatan Politik dalam Mempengaruhi Kebijakan RKUHP

Hukum Pidana dan hukum pidanan yang dikeluarkan oleh pemerintah Jepang dihapuskan.

Dapat dijadikan alasana bahwa selain KUHP sendiri sudah berusia selama dari seratus tahun lebih dan dianggap sudah tidak sesuai dengan semangat dan kebutuhan perkembangan zaman, lebih lanjut KUHP adalah peninggalan kolonial Belanda ini juga disusun berlandaskan muatan sosiologi hukum masyarakat Belanda yang secara lahiriah berbeda dari muatan sosiologi hukum masyarakat Indonesia. Bahkan tidak pernah ada sebelumnya teks resmi KUHP yang merupakan terjemahan dari WvSNI oleh negara. KUHP yanng digunakan hingga kini hanya dari terjemahan tidak resmi yang dikeluarkan oleh pakar hukum pidana, sehingga anggota legislatif membuat kebijakan berupa RKUHP ini diakhir masa jabatannya pada tahun 2019 lalu.

\section{METODE PENELITIAN}

Penelitian ini merupakan sebuah penelitian deskriptif dengan pendekatan kualitatif, fokus penelitian yang diangkatkan ialah partisipasi politik mahasiswa Universitas Negeri Padang khusnya dalam mempengaruhi kebijakan RKUHP, penelitian dilakukan di Universitas Negeri Padang, pemilihan informan dilakukan berdasarkan purposive sampling dengan menentukan informan kunci, dan informan non kunci diperoleh berdasarkan petunjuk dari informan kunc. Teknik pengumpulan data dilakukan dengan cara, jika data Primer diperoleh secara langsung dari responden melalui proses wawancara saja, karena observasi tidak bisa dilakukan sebab kejadian sudah bersifat lampau yaitu tahun 2019 lalu. Sedangkan data sekunder dikumpulkan untuk melengkapi data primer diperoleh melalui studi kepustakaan, arsip dan dokumentasi.
HASIL DAN PEMBAHASAN

Kekuatan Politik Mahasiswa Universitas Negeri Padang dalam Mempengaruhi Kebijakan RKUHP

Dalam kekikutsertaanya untuk mempengaruhi kebijakan RKUHP, tindakan yang diambil oleh mahasiswa Universitas Negeri Padang dijelaskan oleh Indra Kurniawan selaku Presma BEM UNP sekaligus koordinator lapangan dalam aksi penolakan terhadap RKUHP sebagai berikut ini:

“....Kalau di Mahasiswa UNP bisa lah kita liat dari rentetan aksi, yang awalnya kita melakukan kajian dulu kemudian melakukan konsolidasi baru aksi, itu aja sih sebenarnya. Nah dari ketiga itu yang lebih diutamakan buat membuat kajian ya anggota aliansi dan masing-masing PJ nya diberikan kepada kampus lalu nanti kita adakan konsolidasi kalau konsolidasi kita itu sifatnya mengkoordinasi masing-masing BEM diseluruh fakultas, nah nanti masingmasing BEM fakultas melakukan ajakan atau agitasi dimasing-masing jurusan untuk mengajak turun aksi bersama bahwa ada pasal-pasal kontroversial di RKUHP yang harus kita sampaikan kepada pemerintah".

Indra juga menjelaskan bahwasannya mahasiswa Universitas Negeri Padang juga turun serta untuk berdiskusi dengan legislatif, meskipun pada tingat daerah yaitu Sumatera Barat hanya bisa membahas peraturan bersifatnya kedaerahan saja.Lebih lanjut ia juga menjelaskan bahwa mahasiswa juga melaksanakan aksi kamisan serta drama tektrikal dijalan.

BEM UNP yang tergabung kedalam BEM SB, dan BEM SB sendiri merubakan bagian dari BEM SI, yang artinya tindakan yang diambil untuk menolak RKUHP ini mesti berdasakan pada instruksi BEM SI, Muhammad Yusuf selaku ketua politik kajian dan strategis menjelaskan bahwa mahasiswa Universitas Negeri Padang dalam mengkaji kebijakan ini dengan mengandalkan tim politik kajian dan strategis, upaya pengkajian ini dilakukan 
setelah sebelumnya melakukan konsolidasi lebih dulu dengan mengkoordinasikan semua gubernur BEM dari kedelapan fakultas di UNP untuk menyampaikan pandangan mengenai kebijakan RKUHP dan tindakan yang dapat diambil. Namun jika menilik koordinasi mahasiswa UNP dengan universitas lain dijelaskan bahwasannya terkhusus bagi aksi atau tindakan yang dimotori oleh BEM UNP itu lebih dulu sudah didasarkan pada musyawarah di BEM SB, karena BEM UNP tergabung kedalam Aliansi BEM SB.

Dalam memobilisasi masa untuk ikut berpartisiapasi, anggota BEM melakukan agitasi melalui media sosial. Anggota BEM UNP membuat gerakan media sosial yang menyuarakan tuntutan terhadap RKUHP ini. Hal ini dapat dikatakan cukup efektif karena mahasiswa UNP yang mengikuti akun sosial media resmi BEM ikut merepostposting-an tersebut. Terkhusus untuk pengumuman aksi itu juga dilakukan melalui akun instagram dan membagikan digrub-grub whatsapp MaBa 2019 pada saat itu.Aksi yang diikuti oleh mahasiswa Univesitas Negeri Padang yaitu pada tanggal 23 September2019, 24 Septmber 2019, 25September 2019. terkuhusus untuk aksi pada tanggal 24 September itu tidak murni penolakan terhadap RKUHP akan tetapi bertemakan hari tani namun masih menyelipkan tentang RKUHP.

Berdasarkan pengakuan Indra Kurniawan selaku Presma BEM UNP, nahwa kasi pada tanggal 23 September itu berlansung kondusif dan pada saat itu tuntutan mahasiswa diteima dan diteruskan kepusat. Sementara itu demonstrasi pada tanggal 24 September 2019 adalah aksi yang bertemakan hari tani namun masih menyelipkan penolakan mengenai RKUHP, pada akhir-akhir aksi diwarnai ricuh dengan aparat hingga video-video pendek mengenai jalannya aksi tanggal 24 September ini ramai dimedia sosial. Sementara itu demontrasi yang paling ramai dibicarakan yaitu demostrasi menolak RKUHP yang diikuti oleh mahasiswa UNP pada 25 September 2019. berdasarkan pada penelitian diatas ada dua pendapat soal siapa yang menggerakan demostrasi ini, yang pertama berpendapat demostrasi ini digerakkan oleh IMAMIRA dan kedua berpendapat digerakkan oleh BEM FBS UNP bersama BEM FISIP UNAND. Terlepas dari siapa yang memprakarsai aksi tanggal 25 September 2019 ini, mahasiswa Universitas Negeri padang juga mendapat panggilan untuk turun kejalan dari grubgrub jurusan bahkan pada salah satu grub jurusan mengatas namakan BEM UNP, yang pada kenyataanya menahan masa UNP untuk turun aksi pada hari itu.

Sementara itu kajian mengenai RKUHP ini yang dibuat oleh kementerian politik kajian strategis UNP sebagai berikut:

Pertama, pasal 2 ayat (1), pasal 598 RKUHP tentang hukum nyang hidup di masyarakat. Pasal ini berpotensi memunculkan kriminalitas yang tidak jelas sekaligus memunculkam celah praktik penegak hukum yang sewenang-wenang dimana pasal tersebut dimana pasal tersebut dapat ditafsirkan sesuai kepentingan dari kelompok dan penguasa atau kelompok yang mencoba menghegemoni masyarakat.

Kedua, permasalahan pasal yang mengatur tentang makar. RKUHP mengatur tentang makar dalam tiga jenis yaitu makar terhadap presiden, makar terhadap NKRI, dan makar terhadap pemerintah. Menurut Ayuni (2018) klausul makar terhadap pememrintah yang sah memiliki potensi bertentangan dengan pasal 7A dan 7B UUD 1945, selain itu pasal maar ini juga berpotensi untuk memberangus kebebasaan berekpresi, berpendapat, dan pengawasan dari oposisi.

Ketiga, pasal 281-282 tentang kriminalisasi tindak pidana contempt of court, tindak pidana dari pasal ini dapat mengekang kebebasan pers, termasuk dalam hal ini dapat mengekang kebebasan berpendapat yang bertentangan dengan nafas demokrasi. Keempat, RKUHP pasal 218, pasal 219 RKUHP tentang penghinaan terhadap presidem, pasal 240-241 RKUHP tentng penghinaan terhadap pemerintah yang sah. Dalam draft RKUHP istilah "tindak 
Rima Arfa Solia, Lince Magriasti | Partisipasi Politik Mahasiswa Universitas Negeri Padang sebagai Bagian dari Kekuatan Politik dalam Mempengaruhi Kebijakan RKUHP

pidanan penghinaan presiden" berganti dengan "Penyerangan kehormatan atau Harkat dan Martababat Presiden dan Wakil Presiden" yang merupakan sebuah kemunduran demokrasi.

Kelima, Pasal 604-607 RKUHP tentang tindak pidana korupsi, pasal ini berpotensi membukka celah transaksional atau praktik korupsi dagang pasal anatar penegak hukum dengan tersangka atau terdakwa. Selain itu dengan masuknya korupsi pada pasal-pasal RKUHP akan mengurangi bobot kejahatan korupsi.. Oleh karena itu mahasiswa menilai produk hukum RKUHP ini bersifat represif atau cenderung didominasi oleh lembaga legislator dan memuat hal-hal ambigu. Berdasarkan pada penjelasan diatas, dapat ditarik kesimpulan bahwa RKUHP ini mendapat banyak penolakan dari publik, tidak melibatkan lintas disiplin dalam pembahasan, dan mengandung banyak pasal karet, jauh dari tolak ukur responsif dan cenderung represif.

Tuntutan mahasiswa Sumatera Barat khususnya yang diikuti oleh mahasiswa UNP, semua tuntutan yang disampaikan oleh mahasiswa diterima oleh DPRD dan akan diteruskan kepusat, sementara hasil yang diperoleh dari upaya mahasiswa pada saat itu melalui ketetapan presiden bahwasannya RKUHP ini akan ditunda pengesahaanya, secara resmi BEM UNP melakukan tinjauan kembali pada 30 September 2019 setelah tanggal 23 melakukan aksi dan pihak DPRD memberikan pernyataan kalau RKUHP akan ditunda dan dilakukan pengkajian ulang. Pasca aksi 25 Setember praktis tidak ada lagi mobilisasi masa di UNP untuk mempengaruhi kebijakan RKUHP tapi kalau dalam forum atau diskusi yang berada dalam organisasi RKUHP masih jadi pokok bahasan, kedepannya jika kebijakan RKUHP ini sudah dilakukan pengkajian ulang dan hasilnya berpihak pada rakyat serta tidak terdapat pasal karet lagi maka tidak akan ada aksi protes dari mahasiswa namun jika yang terjadi adalah sebaliknya, maka demostrasi terkait RKUHP ini terkhusus di UNP akan kembali dibicarakan.

\section{Faktor-Faktor yang Mempengaruhi Partisipasi Politik Mahasiswa Universitas Negeri Padang}

a) Sosial dan Ekonomi

Terkait dengan faktor sosial dan ekonomi ini, mahasiswa UNP lebih cenderung mengkaitkan dengan pendidikan politik yanng mereka dapatkan dibangku perkuliahan dan menempatkan diri sebagai kaum intelektual ditengah-tengah masyarakat. Dalam kehidupan perkuliahan keseluruhan mahasiswa mendapat pendidikan kewarganegaraan dan pancasila, namun bagi jurusan tertentu memang ada yang mendapat pendidikan politik secara dalam dibangku perkuliahaan. Serta ceramah dosen didalam kelas yang juga memiliki pandangan terhadap politik ikut mendorong mahasiswa untuk berpartisipasi. Serta pendidikan politik yang mahasiswa dapatkan didalam organisasi juga menjadikan mahasiswa lebih melek politik sekalipun bukan mahasiswa dengan latar belakang jurusan politik. Namun dari penelitian yang dilakukan diketahui bahwa ini bukanlah faktor utama dari partisipasi mahasiswa.

\section{b) Faktor Situasi}

Diketahui bahwa tahun 2019 adalah tahun politik meskipun demikian masalah pilihan publik dan sentimentil akan hal tersebut bukan lagi menjadi alasan utama mahasiswa untuk menolak RKUHP ini, jika pada sebelumnya mahasiswa menjadika eksekutif sebagai objek maka pada RKUHP ini mahasiswa lebih menyoroti legislatif. Namun adapun situasi yang dimaksud yaitu ketika mahasiswa melihat lingkungan sekitar semisal petani atau peternak kemudian mereka membenturkan dengan muatan salah satu pasal yaitu apabila ternak masuk kehalaman orang lain maka dapat dipidanakan, hal tersebut memantik sentimentil mahasiswa atau bagi mereka yang mengangap hal tersebut khususnya di Sumbar ini hal-hal remeh seperti diatas 
dapat diselesaikan dengan mufakat saja. Selain itu tuntutan agar pemerintah merevisi UU KPK yang dapat melemahkan KPK juga menjadi sentimentil tersendiri bagi mahasiswa untuk ikut dalam menolak RKUHP, karena waktu itu tuntutan akan kedua kebijakan tersebut disandingkan. Berita politik yang banyak dibagikan dimedia sosial yang belum jelas kebenarannya juga meruapakan faktor tersendiri bagai mahasiswa UNP untuk ikut berpartisipasi mempengaruhi kebijakan RKUHP ini.

\section{c) Afiliasi Politik Orang Tua}

Kecendrungan politik orang tua atau keikutsertaan orang tua dalam politik tidak begitu berpengaruh, informan menajawab kalau orang tua mereka menginginkan anaknya belajar dibagku kuliah dengan pendidikan formal didalam kelas, dan melihat demostrasi secara negatif dari kerusuhaan mahasiswa yang sering ditampilkan di televisi. Namun sebuah pendapat berbeda peneliti temukan pada salah satu informan yang memiliki kerabat dengan usia relatif muda dan tergabung kedalam politik, ia mengakui sering melakukan diskusi untuk membahas isu politik baik dimeja makan maupun diruang keluarga. Tapi tetap saja hal ini bukan merupakan motivasi utama untuk ikut mempengaruhi kebijakan RKUHP ini.

\section{d) Pengalaman Berorganisasi}

Dalam penelitian ini jika membandingkan jawaban aktif berorganisasi dan mahasiswa yang tidak aktif dalam organisasi, terdapat perbedaan dari alasan mereaka untuk turun aksi. Mahasiswa yang aktif berorganisasi cenderung lebih memahami pokok kajian dan muatan di RKUHP dan mereka mengikuti aksi karena menyadari perannya sebagai penyambung suara rakyat dan paham akan konteks yang disuarakan, sementara mahasiswa yang tidak aktif berorganisasi berdasarkan pada berita politik yang diterima disosial media serta ajakan yang disebar digrub jurusan dan juga akun sosial media BEM dan keikutsertaa mereka kadang juga dilatar belakangi oleh ajakan teman atau faktor ikut-ikutan. Secara garis besar dapat dipahami bahwa organisasi cukup mengambil peran besar karena pertamakali penolakan terhadap RKUHP ini dipelopori oleh aktivis.

e) Kesadaran Politik

Dalam kehidupan perkuliahan kesadaran politik lagi-lagi disandingkan dengan keaktifan mahasiswa tersebut dalam berorganisasi, mahasiswa tersebut lebih memliki wadah yang memadai untuk mebahas mengenai masalah politik terkhusus RKUHP ini dan ketika turun aksipun mereka memiliki landasan yang jelas untuk turun aksi. Namun kesadaran politik yang cukup rendah didapat dari mahasiswa yang sebagian besar tidak aktif dalam berorganisasi. Hal ini terbukti dengan pemahaman mereka terhadap muatan RKUHP serta kemampuan mereka menyaring berita disosial media, lebih lanjut dapat dilihat ketika mahasiswa tersebut mengikuti demostrasi dan membawa poster yang aneh-aneh dan dianggap terlalu vulgar atau ada yang tidak memiliki kaitan dengan RKUHP. Kesadaran mereka semangkin dipertanyakan ketikan mengakui keikutsertaan dikarenakan teman atau ikutikutan saja.

f) Kepercayaan terhadap Pemerintah

Meskipun pada dasarnya penolakan RKUHP ini ditujukan kepada legislatif, namun saat BEM UGM memberikan opsi kartu merah dan menyatakan ketidak percayaan terhadap pemerintah hal tersebut sudah menyinggung kepercayaan mahasiswa terhadap pemerintah yang berlansung saat itu, terlebih disaat mahasiswa mempermasalahkan RKUHP presiden juga belum mengambil sikap yang tegas saat RKUHP sudah diributkan oleh mahasiswa, hal ini juga kemudian mempengaruhi kepercayaan mahasiswa terhadap pemerintah dan mendorong untuk turun aksi lagi. Yang terakhir pada saat isu 
Rima Arfa Solia, Lince Magriasti | Partisipasi Politik Mahasiswa Universitas Negeri Padang sebagai Bagian dari Kekuatan Politik dalam Mempengaruhi Kebijakan RKUHP

RKUHP ini mencuat kedepan publik begitu banyak berita yang tersebar di media sosial yang kemudian mempengaruhi citra pemerintah dimata mahasiswa dan menjadi faktor mahasiswa untuk ikut berpartisipasi dalalm mempengaruhi kebijkan RKUHP.

\section{Bentuk Partisipasi Politik}

Berdasarkan pada pengamatan peneliti ditambahkan dengan dokumentasi dan hasil wawancara, peneliti dapat mengelompokkan partisipasi mahasiswa UNP dalam mempengaruhi kebijakan RKUHP kedalam partisipasi militanradikal.

Mahasiswa pada hari itu memiliki tingkat kepercayaan yang rendah pada pemerintah dikarenakan presiden tidak mengambil sikap yang jelas, adanya faktor media yang membentuk citra pemerintah sehingga mempengaruhi kepercayaan mahasiswa, dan sikap yang diambil oleh BEM UGM yang menyatakan ketidak percayaan terhadap legislatif dan pemerintah. Disamping kepercayaan yang rendah terhadap pemerintah mahasiswa pada hari itu memilik kesadaraan politik yang tinggi, hal ini dapat peneliti lihat dari pemahaman mahasiswa secara garis besar bahwa RKUHP ini akan merugikan rakyat meskipun mereka tidak mehami secara detail muatan dan kajian mengenai RKUHP ini, dan sebagain mereka yang paham betul muatan RKUHP dan terlibat didalam penyusunan kajian.

Meskipun cara seperti penggiringan opini lewat media sosial gencar dilakukan serta juga ada melakukan konsolidasi dan diskusi namun tidak terlepas dari cara konvensional seperti aksi, dan hal ini tidak lepas dari kericuhan, bentrok dengan aparat, dan pengrusakan barang publik hal tersebut terekam ketika demo yang berlangsung pada 24 September 2019 dan keesokan harinya pada 25 September 2019.

Kepercayaan mahasiswa UNP yang rendah terhadap pemerintah disamping itu memiliki kesadaran politik yang tinggi pada akhirnya melahirkan bentuk partisipasi politik yang cenderung militan radikan, seperti yang dapat dilihat dari penjelasan diatas.

\section{PENUTUP}

Berdasarkan pada hasil penelitian dapat diambil kesimpulan bahwasannya cara yang ditempuh oleh mahasiswa UNP guna mempengaruhi kebijakan RKUHP yaitu melalui demsotrasi, melalui diskusi, dan memanfaatkan media sosial yang ada, dari keseluruhan aksi yang dilakukan tuntutan mahasiswa diterima oleh pihak DPRD dan disampaikan pada ari aksi kepada DPR pusat,Adapun faktor-faktor yang mempengaruhi demostrasi yaitu status pendidikan sebagai mahasiswa, situasi politik pada tahun 2019, pengalaman dalam berorganisasi, afiliasi politik kerabat, kesadaran politik, dan kepercayaan terhadap pemerintah. Semua hal diatas mempengaruhi mahasiswa untuk berpartisipasi namun hanya beberapa yang menjadi landasan kuat mahasiswa Universitas Negeri Padang untuk ikut berpartisipasi pada saat itu, yaitu pengalaman berorganisasi, hal ini menjadi pembeda yang sangat kontras ketika dillihat dari pengetahuan tentang kajian dan muatan RKUHP, antara mahasiswa yang aktif berorganissasi dan tidak, serta ada dua hal lainnya yang sangat kuat sebagai pendorong mahasiswa untuk berpatisipasi yaitu media sosial dan ajakan teman. Keaktifan mahasiswa UNP dimedia sosial membuatnya sensitif akan video atau gambar serta postingan teman-teman yanng mengikuti demo menolak RKUHP ini, sementara ajakan teman juga menjadikan mahasiswa terkesan ikut-ikutan dalam demostrasi ini. Kesadaran politik mahasiswa yang tinggi sementara kepercayaan terhadap pemerintah terbilang rendah melahirkan partisipasi politik mahasiswa berbentuk militan-radikal.

Adapun saran yang dapat diberikan diantaranya adanya upaya untuk meningkatkan pengetahuan mahasiswa Universitas Negeri Padang diperlukan sosialisasi dan pendidikan terkait muatan RKUHP, pelajaran berpolitik, tujuan dan 
kajian dalam demostrasi. Serta perlu juga adanya literasi dan kampanye mengenai bagaimana mahasiswa seharusnya bijak dalam bermedia sosial, Perlu dilakukan ajakan yang lebih persuasif agar mahasiswa mau tergabung kedalam organisasi, karena sejatinya pendidikan politik secara praktis dapat dillihat disana.Meningkatkan koordinasi antar organisasi di Universitas Negeri Padang, agar kasus seperti pada tanggal 25 september tidak terjadi lagi.

\section{DAFTAR KEPUSTAKAAN}

Arbi Sanit. 2012. Sistem Politik Indonesia. Jakarta: PT Grafindo Persada.

Andik Matulessy dkk. 2013. "Political Efficacy, Political Trust, dan Collective Self Esteem dengan Partisipasi dalam Gerakan Mahasiswa". Jurnal Penelitian Psikologi. Volume 04. Nomor 01.

Andrias Darmayadi. 2011. "Pergerakan Mahasiswa dalam perspektif Partisipasi Politik : Partisipasi Otonom atau Mobilisasi". Majalah Ilmiah UNIKOM. Volume 9. Nomor 1.

Anwar Arifin. 2015. Perspektif Ilmu Politik. Jakarta : PT Grafinddo Persada.

Dadi Junaedi Iskandar. 2017. "Pentingnya Partisipasi dan Peranan Kelembagaan Politik dalam Proses Pembuatan Kebijakan Publik". Jurnal Ilmu Administrasi. Volume 14. Nomor 1.

Doni Hendrik. 2010. "Variabel-Variabel yang Mempengaruhi Rendahnya Partisipasi Politik Masyarakat dalam Pilkada Walikota dan Wakil Walikota" Padang Tahun 2008. Jurnal Demokrasi. Volume 9. Nomor 2.

Maya Yuliantina. 2016. Pengaruh Kesadaran politik terhadap Partisipasi Politik dalam Pemilihan Kepala Desa di Desa Hajimena Kecamatan Natar Kabupaten Lampung Selatan. Skripsi.
Fakultas Ilmu Sosial dan Politik, Universitas Lampung, Bandar Lampung. $\quad 116 \quad$ Halaman (dipublikasikan).

Taufiqurokhman. 2014. Kebiajkan Publik.. Jakarta Pusat : Fakultas Ilmu Sosial dan Ilmu Politik Universitas Moestopo Beragama (Pers) 